\title{
PROFIL KESALAHAN MAHASISWA PADA MATA KULIAH ANALISIS KOMPLEKS
}

\author{
Nely Indra Meifiani ${ }^{1}$ \\ ${ }^{1}$ Program Studi Pendidikan Matematika, STKIP PGRI Pacitan \\ email: indrameifiani@yahoo.co.id
}

\begin{abstract}
This research is used to analyze the error profile encountered by STKIP PGRI Pacitan students in the course of Complex Analysis on the subject of Polar Shape. The type of research used is qualitative descriptive. Subjects used as many as 2 students. Data collection methods used are test methods and interview methods. The results of this study are on Misunderstanding, Transformation Errors and Process Errors. Misunderstanding is to assume the symbol $R=r$ when $R \neq r$. Then assume that in calculating the root of the value of negative/positive just the same, even though the end result also remains the same. And it is often reversed between the values of $x$ and $y$. Transformation error is inverted in determining $x$ and $y$ for cos arc formula. While the Process Error is unable to determine the magnitude of a special angle adjusted to the location of the point of $z$. weak in calculating the powers in the form of fractions. And wrong in drawing the z-point coordinates.
\end{abstract}

Keywords: profile, error, complex analysis

\section{A. PENDAHULUAN}

Sistem pendidikan nasional dikembangkan salah satunya melalui proses pembelajaran. Proses pembelajaran tersusun atas sejumlah komponen atau unsur yang saling berkaitan satu sama lainnya. Interaksi antara dosen dan mahasiswa pada saat belajar mengajar memegang peran penting dalam mencapai tujuan yang diinginkan. Tujuan pembelajaran adalah pencapaian prestasi yang baik dari para mahasiswanya. Biasanya untuk mengukur capaian tujuan pembelajaran, dosen biasanya menggunakan tes. Sebuah alat ukur yang digunakan untuk mengukur sejauh mana kemampuan kognitif seseorang terhadap materi yang telah diajarkan oleh dosen.

Mardapi (2008:1) menyatakan ada tiga istilah yang sering digunakan dalam evaluasi, yaitu pengukuran, asesmen, dan evaluasi. Kuis adalah kegiatan pengukuran pencapaian kompetensi mahasiswa pada pokok bahasan tertentu. Kuis dilaksanakan diakhir sesi pertemuan setelah materi selesai diberikan. Hasil kuis digunakan untuk mengukur sejauh mana daya serap mahasiswa terhadap pokok bahasan tertentu. Tentu saja pengajar melihat terlebih dahulu kesiapan mahasiswanya. 
Kuis ini digunakan untuk mengukur daya serap mahasiswa pada materi Bentuk Kutub, di mana pada bagian ini sarat sekali trigonometri. Peneliti ingin sekali mengukur sejauh mana tingkat pemahaman trigonometri yang sebenarnya sudah diperoleh mahasiswa ketika mereka duduk di bangku sekolah menengah. Materi trigonometri diperkuat lagi di awal semester dengan mahasiswa telah menempuh mata kuliah aljabar dan trigonometri. Karena peneliti mendapati beberapa mahasiswa kesulitan ketika mulai bermain dengan rumus sinus, cosinus, tangent, dan kawankawannya. Padahal pada mata kuliah ini apalagi pada materi bentuk kutub, trigonometri harus dipahami dengan baik oleh para mahasiswa sebagai modal dasar mata kuliah ini. Karena jika mahasisw tidak paham atau bingung dengan trigonometri kemungkinan besar mahasiswa tersebut akan kesulitan dalam mengikuti mata kuliah Analisis Kompleks.

Trigonometri pada mata kuliah analisis kompleks tidak hanya pada bentuk kutub saja, tetapi semakin kebelakang semakin banyak penggunaan trigonometri yang lebih tinggi lagi. bentuk kutub baru sekedar pemahaman awal sebagai intro penggunaan trigonometri pada mata kuliah ini.

Harapan peneliti dengan semakin cepatnya tingkat keterukuran kesalahan mahasiswa pada pokok bahasan ini, maka akan lebih cepat pula segera tertangani oleh peneliti. Karena ini merupakan modal awal mahasiswa untuk melangkah ke pokok bahasan yang tentunya lebih sulit dengan menggunakan materi trigonometri.

\section{B. KAJIAN LITERATUR}

\section{a. Kesalahan Siswa}

Prosedur Newman untuk menganalisis kesalahan memiliki beberapa level, yaitu: Reading, Comprehension, Transformation, Process skill, dan Encoding. (Prakitipong dan Nakamura, 2006:124)

Menurut Newman (White, 2005:17) mengklasifikasikan kesalahan siswa dalam menyelesaikan soal matematika sebagai berikut:

1) Reading (Kesalahan membaca)

Yaitu kesalahan yang terjadi jika siswa tidak mampu membaca kata kunci atau simbol pada soal sehingga siswa tidak dapat me-langkah lebih lanjut pada pola pemecahan masalah yang tepat.

2) Comprehension errors (Kesalahan pemahaman)

Yaitu kesalahan yang terjadi jika siswa sudah mampu membaca semua kata dalam soal, akan tetapi tidak menguasai secara menyeluruh pengertian kata-kata tersebut, siswa tidak dapat melangkah lebih lanjut pada pola pemecahan masalah yang tepat. 
3) Transformation Errors (Kesalahan transformasi)

Yaitu kesalahan yang terjadi jika siswa telah mampu memahami apa yang diinginkan soal akan tetapi tidak mampu mengidentifikasi operasi atau pola operasi yang dibutuhkan untuk memecahkan masalah.

4) Processing Skill Errors (Kesalahan proses penyelesaian)

Yaitu kesalahan yang terjadi jika siswa telah mengidentifikasi operasi atau pola operasi yang tepat, akan tetapi tidak mengetahui prosedur yang diperlukan untuk menyelesaikan operasi tersebut secara akurat.

5) Encoding Errors (Kesalahan menarik kesimpulan)

Yaitu kesalahan yang terjadi jika siswa telah menemukan solusi atas permasalahan, akan tetapi salah dalam menuliskan jawaban akhir.

Berdasarkan teori yang dikemukakan oleh Newman di atas telah dijelaskan secara detail bahwa kesalahan siswa sebenarnya memiliki 5 level. Akan tetapi pada kajian ini peneliti akan menggunakan level ke 2, ke-3 dan ke 4 saja.

\section{METODE PENELITIAN}

Jenis penelitian yang digunakan adalah penelitian deskriptif dimana digunakan untuk mendeskripsikan profil kesalahan yang dihadapi oleh mahasiswa dalam menyelesaikan kasus Bentuk Kutub pada mata kuliah Analisis Kompleks. Pendekatan analisis yang digunakan adalah pendekatan kualitatif deskriptif.

Subjek yang digunakan sebanyak 2 mahasiswa dari 24 mahasiswa yang mengikuti mata kuliah Analisis Kompleks.

Metode pengumpulan data yang digunakan adalah metode tes dan wawancara.

\section{HASIL DAN PEMBAHASAN}

Dari 24 mahasiswa yang mengikuti kuis diperoleh hasil yaitu mahasiswa yang nilai kuisnya mendapat $\mathrm{A}$ ada 7 orang mahasiswa, mendapat $\mathrm{B}$ ada 2 orang mahasiswa dan sisanya $\mathrm{C}$ dan D. Hasil yang cukup tidak memuaskan karena sekitar 15 orang mahasiswa nilainya tidak sesuai harapan.

Berikut ini akan diuraikan kesalahan yang dilakukan oleh seorang mahasiswa berinisial JS dan DC. di mana JS dan DC melakukan banyak sekali kesalahan.

\section{Soal No 1}

$$
z=-2-2 i
$$

a. Menentukan $r$

Mahasiswa salah dalam menuliskan symbol r. mahasiswa menggunakan $\mathrm{R}$ besar. Padahal di matematika $R \neq r$. Mahasiswa salah mensubtitusikan nilai y 
yang seharusnya -2 dan salah menghitung hasil akar kuadrat

$$
\sqrt{(-2)^{2}+(2)^{2}}=2
$$

dan

$$
\sqrt{(-2)^{2}+(-2)^{2}}=\sqrt{(2)+(2)}=2
$$

b. Menentukan $\theta$

Mahasiswa kurang tepat dalam menentukan $\theta$ dari $\operatorname{arc} \operatorname{tg} 1$

$$
\operatorname{arctg} 1=45^{\circ}
$$

Memang benar hasilnya seperti itu tetapi nilai $\theta=45^{\circ}$ yang terletak di kudran 1 tidak pas jika dikondisikan dengan posisi $x$ dan $y$ pada soalnya yang posisi kuadrannya adalah di kuadran 4. Kesalahan yang disebabkan kesalahan sebelumnya. Di mana nilai $r=2 \sqrt{2}$ tetapi dijawab 2. Sehingga salah dalam menentukan nilai $\operatorname{arc} \sin \theta$.

c. $\arg (\mathrm{z})$

Karena nilai $c$ sudah salah maka otomatis nilai $\arg (\mathrm{z})$ juga salah

d. $\operatorname{Arg}(\mathrm{z})$

Karena nilai $\theta$ sudah salah maka otomatis nilai $\operatorname{Arg}(\mathrm{z})$ juga salah

e. z dalam bentuk kutub

Karena nilai $\mathrm{r}$ dan $\theta$ sudah salah maka otomatis $\mathrm{z}$ dalam bentuk kutub juga salah

f. Gambar z dalam sebuah grafik kartesius

Mahasiswa menggambarkan koordinatnya pada kuadran 1 yaitu $(2,2)$ yang seharusnya pada kuadran 3 sesuai dengan soal $z=-2-2 i \rightarrow(-2,-2)$, namun mahasiswa tidak bisa mentukan koordinat titik $\mathrm{Z}$.

\section{Soal No 2}

$z=\frac{1}{2}-\frac{1}{2} \sqrt{3} i$

a. Menentukan $r$

Mahasiswa salah dalam menuliskan symbol r. mahasiswa menggunakan $\mathrm{R}$ besar. Padahal di matematika $R \neq r$. Mahasiswa salah mensubtitusikan nilai y yang harusnya $-\frac{1}{2} \sqrt{3}$ dan salah menghitung hasil akar kuadrat

dan

$$
\sqrt{\left(\frac{1}{2}\right)^{2}+\left(\frac{1}{2} \sqrt{3}\right)^{2}}=\sqrt{4}=2
$$

$$
\sqrt{\left(\frac{1}{2}\right)^{2}+\left(-\frac{1}{2}\right)^{2}}=0.75
$$

b. Menentukan $\theta$

Mahasiswa salah dalam menentukan $\theta$ dari $\operatorname{arctg} \sqrt{3}$

$$
\operatorname{arctg} \sqrt{3}=60+180=240^{\circ}
$$

Kesalahan yang disebabkan kesalahan sebelumnya. Di mana nilai $r=$ 1 tetapi dijawab 0.75 . Sehingga salah dalam menentukan nilai $\operatorname{arc} \cos \theta$.

c. $\arg (\mathrm{z})$

Karena nilai $\theta$ sudah salah maka otomatis nilai $\arg (\mathrm{z})$ juga salah

d. $\operatorname{Arg}(\mathrm{z})$

Karena nilai $\theta$ sudah salah maka otomatis nilai $\operatorname{Arg}(\mathrm{z})$ juga salah 
e. z dalam bentuk kutub

Karena nilai $\mathrm{r}$ dan $\theta$ sudah salah maka otomatis $\mathrm{z}$ dalam bentuk kutub juga salah

f. Gambar z dalam sebuah grafik kartesius

Mahasiswa menggambarkan koordinatnya pada kuadran 3 yaitu $\left(-\frac{1}{2},-\frac{1}{2} \sqrt{3}\right)$ yang seharusnya pada kuadran 4 sesuai dengan soal $z=\frac{1}{2}-\frac{1}{2} \sqrt{3} i \rightarrow\left(\frac{1}{2},-\frac{1}{2} \sqrt{3}\right)$. Selain itu, mahasiswa tidak bisa mentukan koordinat titik Z.

\section{Soal No 3}

$z=-\frac{1}{2} \sqrt{3}-\frac{1}{2} i$

\section{a. Menentukan $\mathrm{r}$}

Mahasiswa salah dalam menuliskan symbol $\mathrm{r}$. mahasiswa menggunakan $\mathrm{R}$ besar. Padahal di matematika $R \neq r$. Mahasiswa salah mensubtitusikan nilai $\mathrm{x}$ dan y yang harusnya $-\frac{1}{2} \sqrt{3}$ dan $-\frac{1}{2}$ kemudian juga salah menghitung hasil akar kuadrat

$$
\sqrt{\left(\frac{1}{2} \sqrt{3}\right)^{2}+\left(\frac{1}{2}\right)^{2}}=\sqrt{4}=2
$$

b. Menentukan $\theta$

Mahasiswa tidak selesai dalam menentukan $\theta$ dari $\operatorname{arctg} \frac{y}{r}$

c. $\arg (\mathrm{z})$

Tidak bisa menetukan nilai $\arg (\mathrm{z})$

d. $\operatorname{Arg}(\mathrm{z})$

Salah dalam menentukan nilai $\operatorname{Arg}(\mathrm{z})$
$\operatorname{Arg}(Z)=210$

Tidak sesuai dengan syarat bahwa nila dari $\operatorname{Arg}(\mathrm{z})$ terletak pada $-\pi<$ $\operatorname{Arg}(z)<\pi$

e. z dalam bentuk kutub

Karena nilai $r$ sudah salah maka otomatis $\mathrm{z}$ dalam bentuk kutub juga salah

f. Gambar z dalam sebuah grafik kartesius

Mahasiswa benar dalam menggambarkan koordinatnya pada kuadran 3 yaitu $\left(-\frac{1}{2} \sqrt{3}, \frac{1}{2}\right)$, namun mahasiswa tidak bisa mentukan koordinat titik $\mathrm{Z}$.

\section{Soal No 4}

$z=6$

a. Menentukan $r$

Mahasiswa salah dalam menuliskan symbol r. mahasiswa menggunakan $\mathrm{R}$ besar. Padahal di matematika $R \neq r$. Mahasiswa benar dalam menghitung $r$

$$
\sqrt{6^{2}+0}=6
$$

b. Menentukan $\theta$

Mahasiswa salah dalam menentukan $\theta$. Salah dalam menentukan nilai $x$ yang seharusya $\mathrm{x}=6$ tetapi diisi $\mathrm{x}=0$

$$
\begin{aligned}
\theta & =\arccos \frac{x}{r} \\
& =\arccos \frac{0}{6} \\
& =\arccos 0
\end{aligned}
$$

Mahasiswa salah dalam menuliskan rumus $\arccos \frac{y}{r}$ dan sekaligus tidak selesai dalam mengerjakan soal. 
c. $\arg (\mathrm{z})$

Karena nilai $\theta$ sudah salah maka otomatis nilai $\arg (\mathrm{z})$ juga salah

d. $\operatorname{Arg}(\mathrm{z})$

Karena nilai $\theta$ sudah salah maka otomatis nilai $\operatorname{Arg}(\mathrm{z})$ juga salah

e. $\mathrm{z}$ dalam bentuk kutub

Karena nilai $\theta$ sudah salah maka otomatis $\mathrm{z}$ dalam bentuk kutub juga salah

f. Gambar z dalam sebuah grafik kartesius

Mahasiswa menggambarkan koordinatnya pada sumbu $x$ negatif seharusnya sumbu x positif.

\section{Soal No 5}

$z=-3 i$

a. Menentukan $\mathrm{r}$

Mahasiswa salah dalam menuliskan symbol r. mahasiswa menggunakan $\mathrm{R}$ besar. Padahal di matematika $R \neq r$. Mahasiswa benar dalam menghitung $\mathrm{r}$

$$
\sqrt{0^{2}+(-3)^{2}}=3
$$

b. Menentukan $\theta$

Mahasiswa kurang tepat dalam menentukan $\theta$ dari $\operatorname{arc} \cos 0$

$$
\arccos 0=90^{\circ}
$$

Memang benar hasilnya seperti itu tetapi nilai $\theta=90^{\circ}$ yang terletak di sumbu y positif tidak pas jika dikondisikan dengan soalnya yang harusnya di sumbu y negatif. c. $\arg (\mathrm{z})$

Karena nilai $\theta$ sudah salah maka otomatis nilai $\arg (\mathrm{z})$ juga salah

d. $\operatorname{Arg}(\mathrm{z})$

Karena nilai $\theta$ sudah salah maka otomatis nilai $\operatorname{Arg}(\mathrm{z})$ juga salah

e. z dalam bentuk kutub

Karena nilai $\theta$ sudah salah maka otomatis $\mathrm{z}$ dalam bentuk kutub juga salah

f. Gambar z dalam sebuah grafik kartesius

Mahasiswa menggambarkan koordinatnya pada sumbu x positif seharusnya sumbu y negatif.

\section{E. SIMPULAN}

Berdasarkan hasil kuis yang telah dikerjakan oleh JS dan DC sangat terlihat bahwa JS dan DC banyak sekali melakukan kesalahan yang sederhana tetapi mengakibatkan fatal untuk seluruh jawabannya. Adapun yang bisa kita tarik kesimpulan dari pekerjaan JS dan DC adalah sebagai berikut.

a. Kesalahan pemahaman

1) Menganggap bahwa symbol $R=r$ padahal dalam matematika $R \neq r$.

2) Menganggap bahwa dalam menghitung akar pangkat nilai negative/ positif sama saja, hal ini terbukti ketika mensubtitusikan nilai ke rumus mengabaikan negatif/positif 
nilai $\mathrm{x}$ dan $\mathrm{y}$ padahal itu tidak dibenarkan walupun hasil akhirnya pun tetap sama.

3) Sering terbalik antara nilai $x$ dan $y$.

b. Kesalahan Transformasi

Terbalik antara $\mathrm{x}$ dan $\mathrm{y}$ dalam menentukan rumus $\arccos \frac{x}{r}$ dengan $\arccos \frac{y}{r}$ c. Kesalahan proses

1) Belum bisa dengan baik menentukan nilai dari sudut-sudut istimewa yang disesuaikan dengan letak titik dari z.

2) Tidak bisa dalam menghitung perpangkatan dalam bentuk pecahan.

3) Salah dalam menggambar koordinat titik z

\section{DAFTAR RUJUKAN}

Mardapi, Djemari. (2008). Teknik Penyusunan Tes dan Nontes. Yogyakarta: Mitra Cendekia Press.

Prakitipong, Natcha \& Nakamura, Satoshi. (2006). Analysis of Mathematics Performance of Grade Five Student in Thailand Using Newan Procedure. Journal international cooperation in education, 9, 111-122. Diakses tanggal 15 Juli 2017 dari http://home.hiroshima-u.ac.jp/cice/9-1 prakitipongnakamura.pdf

White, Allan L. (2005). Active Mathematics In Classrooms: Finding Out Why Children Make Mistake-And Then Doing Something To Help Them. University of Western Sydney: Square one, 15, 4. Diakses tanggal 5 Juli 2017 dari http://www.curriculumsupport.education.nsw.gov.au/primary/mathematics/assets/pdf/s qone.pdf 